\title{
Role Of Financial Intermediaries in Shadow Schemes: Risk-Based Approach
}

http://doi.org/10.21272/fmir.5(3).87-92.2021

Inna Tiutiunyk, ORCID ID: https://orcid.org/0000-0001-5883-2940

Doctor of Economics, Associate Professor, Sumy State University, Ukraine

Yuliia Humenna, ORCID ID: https://orcid.org/0000-0001-5309-6016

$\mathrm{PhD}$, Senior lecturer, Sumy State University, Ukraine

\begin{abstract}
The article is devoted to the study of the role of financial intermediaries in the shadow sector of the economy. The main purpose of the article is to analyze and systematize the work of scientists to assess the risk of shadow transactions with the participation of financial intermediaries. The results of the analysis of scientific publications on these issues show a wide variety of approaches to the study of these problems. Significant differences in the functioning of the financial, banking, insurance and investment markets of different countries have led to the need to develop and implement their own methodologies for assessing the risk of participation of financial intermediaries in shadow transactions at the state level. The paper summarizes the methodological approaches to assessing the risk of participation of financial intermediaries in shadow transactions in some countries. The methodological tools of the analysis are the methods of analysis and synthesis, generalization and comparative analysis. The object of the study are insurance companies, banking institutions and investment funds - participants in shadow schemes of income concealment. The article summarizes the most typical schemes of income concealment in terms of individual groups of financial intermediaries. The conclusion about the dual nature of banking institutions in these operations is made: 1) banking institutions as a "buffer", and sometimes a direct participant on the way to the legalization of shadow income; 2) banking institutions as a subject of primary financial monitoring and control. Insurance operations that are subject to enhanced control by regulatory authorities include: pseudo-insurance operations; concluding an insurance contract with subsequent receipt of compensation for the occurrence of a fictitious insured event; concluding an insurance contract with an inflated insurance value of the object. Based on the analysis of transactions with signs of fictitiousness, which are realized on the investment market of Ukraine, the conclusion about the important role of technical securities in operations on shadowing of incomes and their further legalization is made. The results of the study can be useful for public financial monitoring and control bodies in terms of identifying transactions that could potentially pose a threat to the formal sector of the economy and developing measures to prevent them.
\end{abstract}

Keywords: financial intermediaries, shadowing of the economy, risk, banking institutions, insurance companies, investment funds, securities, investments.

JEL Classification: F63, G17, H3, K220.

Cite as: Tiutiunyk, I., Humenna, Yu. (2021). Role Of Financial Intermediaries in Shadow Schemes: RiskBased Approach. Financial Markets, Institutions and Risks, 5(3), 87-92. http://doi.org/10.21272/fmir.5(3).8792.2021.

Published: 13, September, 2021

Copyright: (C) 2021 by the authors. Licensee Sumy State University, Ukraine. This article is an open access article distributed under the terms and conditions of the Creative Commons Attribution (CC BY) license (https://creativecommons.org/licenses/by/4.0/)

\section{Introduction}

Given the high level of shadowing of the economy in most countries, one of the challenges for international and government institutions is to develop a methodology for estimating the likelihood of shadow entities engaging in economic activities. The stability of the economic system and its attractiveness to international partners depend on the availability of effective tools for assessing the risk of participation of economic entities in shadow operations. 
To date, international scientists and public authorities in some countries have developed a number of approaches to assessing the risk of shadowing the economy, which differ in the set of indicators and entities in terms of which the assessment is conducted (Almenar et. al., 2020; Del'Anno, 2003; Doyle et. al., 2016; Mikulić, 2021; Shumska \& Nezhyvenko, 2013). Thus, the shadow sector of the economy in different countries differs in the list of drivers of its ex Del'Anno existence, the totality of which is determined by the peculiarities of their economic systems, the level of international cooperation, efficiency of state regulatory authorities, and the level of tax morale in society.

\section{Literature Review}

The high level of shadowing in most countries leads to the need to implement a methodology for assessing the risk of shadowing of income at the state level, which would take into account the structure of the financial market, the degree of development of individual sectors, the role of financial intermediaries in the shadow economy. Significant differences in the functioning of the shadow sector of the economy lead to a significant variety of approaches to assessing the risk of shadowing of income, money laundering and territorial financing (Table 1).

Table 1. Methodology for national risk assessments

\begin{tabular}{|c|c|c|}
\hline Country & Methodology for national risk assessments & Year \\
\hline Armenia & National Assessment of Money Laundering and Terrorism Financing Risk in the Republic of Armenia & 2014 \\
\hline Australia & $\begin{array}{l}\text { Australia's non-profit organisation sector: money laundering and terrorism financing risk assessment } \\
\text { Terrorism Financing in Australia } \\
\text { Money Laundering in Australia }\end{array}$ & $\begin{array}{l}2017 \\
2014 \\
2011\end{array}$ \\
\hline Austria & Nationale Risikoanalyse Österreich & 2015 \\
\hline Belarus & National Risk Assessment - Summary & $\begin{array}{l}2014- \\
2017\end{array}$ \\
\hline Canada & $\begin{array}{l}\text { Assessment of Inherent Risks of Money Laundering and Terrorist Financing } \\
\text { Tendances et analyse des risques en }\end{array}$ & $\begin{array}{l}2015 \\
2014\end{array}$ \\
\hline Croatia & National Money Laundering and Terrorist Financing Risk Assessment Report & 2016 \\
\hline Cyprus & National Assessment of Money Laundering and Terrorist Financing Risks & 2018 \\
\hline $\begin{array}{l}\text { Czech } \\
\text { Republic }\end{array}$ & Report on the First Round of National Money Laundering and Terrorist Financing Risk Assessment & 2016 \\
\hline Denmark & $\begin{array}{l}\text { Money Laundering in Denmark - National Risk Assessment } \\
\text { National Risk Assessment on Terrorist Financing in Denmark }\end{array}$ & $\begin{array}{l}2015 \\
2019\end{array}$ \\
\hline Greece & Money Laundering Risk Assessment & 2018 \\
\hline Ireland & National Risk Assessment for Ireland & 2016 \\
\hline Italy & $\begin{array}{l}\text { National Assessment of Money-Laundering and Terrorist Financing Risks National risk assessment of } \\
\text { money laundering and terrorist financing }\end{array}$ & $\begin{array}{l}2014 \\
2018\end{array}$ \\
\hline Japan & National Risk Assessment of Money Laundering and Terrorist Financing & 2017 \\
\hline Latvia & Latvian National money laundering/terrorism financing risk assessment report & 2017 \\
\hline Lithuania & Lithuanian National Risk Assessment of Money Laundering and Terrorist Financing & 2015 \\
\hline Luxembourg & National risk assessment of money laundering and terrorist financing & 2018 \\
\hline Netherlands & $\begin{array}{l}\text { National Risk Assessment on Terrorist Financing } \\
\text { National Risk Assessment Money Laundering report } \\
\text { National Risk Assessment Terrorist Financing report }\end{array}$ & 2017 \\
\hline Portugal & Avaliação nacional de riscos de branqueamento de capitais e de financiamento do terrorismo & 2015 \\
\hline Sweden & $\begin{array}{l}\text { National Money Laundering Risk Assessment } \\
\text { Understanding Terrorist Finance, Modus Operandi and National CFT Regimes } \\
\text { National Money Laundering Risk Assessment } \\
\text { National Terrorist Financing Risk Assessment }\end{array}$ & $\begin{array}{l}2015 \\
2015 \\
2013 \\
2014\end{array}$ \\
\hline Ukraine & $\begin{array}{l}\text { National Risk Assessment Report on Preventing and Countering Legalization (Laundering) of Proceeds } \\
\text { of Crime and Financing of Terrorism }\end{array}$ & 2016 \\
\hline Germany & National risk assessment of Germany & 2018 \\
\hline Finland & National Risk Assessment of Money Laundering and Terrorist Financing & 2015 \\
\hline France & Tendances et analyse des risques de blanchiment de capitaux et de financement du terrorisme en & $\begin{array}{ll}2017- \\
2018\end{array}$ \\
\hline Uruguay & National Risk Assessment of Money Laundering and Terrorist Financing & 2014 \\
\hline
\end{tabular}

Source: Illicit Financial Flows, 2020; Almenar et. al., 2020; Del'Anno, 2003; Doyle et. al., 2016; Mikulić, 2021; Shumska \& Nezhyvenko, 2013.

In addition to government institutions, the assessment of the risk of shadowing the economy attracts the attention of a large number of scientists in different countries. Investigating the role of banking institutions in 
shadow operation, Favarel-Garrigues et al. (2007) emphasizes the responsibility of bank employees who work with customers for risk assessment in the implementation of operations on account opening, savings, withdrawals and transfers. According to Johnson (2003), the assessment of the risk of shadowing of income with the participation of banking institutions should be based on the intuition of the bank employee and his prudence. If a client is assigned to a group of clients with high or low risk, a bank employee must suspend the implementation of a banking transaction with this client.

At the same time, theoretical and methodological developments in the risk of participation of investment funds, insurance companies and other financial intermediaries are virtually absent.

\section{Methodology and research methods}

The methodological basis of the paper is the methods of generalization and synthesis, comparative analysis.

\section{Results}

The results of the analysis indicate the availability of a wide range of tools for assessing the risk of shadowing the economy. At the same time, most approaches focus on individual operations or activities by sector of the economy, while ignoring the study of the likelihood of financial intermediaries participating in shadow transactions.

Within the study, the risk of financial intermediaries' participation in shadow transactions will be understood as the probability of carrying out shadow transactions with the direct or indirect participation of financial intermediaries.

The probability of financial transactions is considered in terms of the following intermediaries:

1) the risk of shadow operations with the participation of representatives of the banking sector of the economy. Today, the role of the banking sector in the development of the shadow sector of the economy is crucial (Koldovsky, 2008; Farhi. \& Tirole, 2017; F"eve \& Pierrard, 2017). Banking institutions are a "buffer" on the way to legalization of illegally obtained income. Very often, banks, as the main financial intermediaries in attracting and placing financial resources, are the subjects of primary financial monitoring, the main function of which is to inform the authorities about the implementation of suspicious financial transactions that can be classified as illegal.

In the context of digitalization of the economy, the pace of which under the influence of the Covid-19 pandemic has accelerated significantly, in the global financial market due to most payments in non-cash form there is a significant reduction in cash turnover (Tiutiunyk et al., 2021). Given these trends, criminals who receive income from shady or illegal activities are forced to legalize their income by legalizing it in the financial system, while minimizing suspicions about the sources of their receipt.

In general, the process of legalization of illicit income through the banking sector can be affected in the form of a scheme (Figure 1).

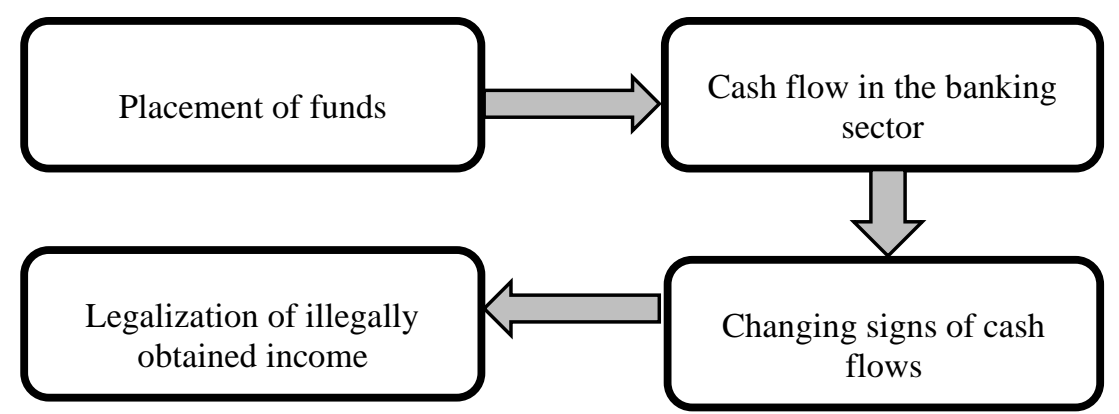

Figure 1. Legalization of illegally obtained income through banking institutions

Source: Compiled by the author.

Revenues received in the shadow sector of the economy go to the country's financial system through their placement in banking institutions. The next stage is the masking of illegally obtained income and their maximum separation from the illegal source of their origin. 
One of the most common operations in this direction is lending to fictitious companies, followed by payment for the services of third parties. The purchase of certain tangible or financial assets at the expense of illegally obtained income contributes to their faster entry into the real sector of the country's economy with their subsequent legalization. Relaxation of these transactions is carried out mainly in order to avoid suspicions of law enforcement agencies about the legality of the source of these revenues.

Quite often the opening of single accounts contributes to the achievement of these goals. Thus, the subjects of the shadow economy with the help of a newly established firm (usually operates for less than a year) open accounts in various commercial banks, make illegally received income on deposit (in small shares), and then carry out operations to legalize these funds.

No less common are transactions to pay obligations under non-existent contracts. Thus, economic entities by falsifying documents, which indicate the data of non-existent transactions (terms of the contract and the amount of payment) transfer significant amounts of money through banks. The subject of the contract, as a rule, are certain services, less tangible assets.

A common tool for laundering illegally obtained income is the accrual of salary payments or remuneration in favor of an individual or legal entity through banking institutions. Implementation of these operations allows for tax evasion and legalization of shadow income.

2) the risk of realization of shadow operations by the subjects of the insurance market. Today, insurance transactions are a fairly common tool for shadowing income (Hepfer et al., 2016; Melnyk et al., 2021). Shadow market participants have developed a wide range of tools for concealing income with the help of insurance companies. In this case, the objects of insurance are a significant number of material goods and services. Securities are most often used in fictitious insurance schemes. The basis of these operations is the withdrawal of funds abroad or their conversion into cash. Thus, according to the results of the analysis of insurance companies 'performance in Ukraine for the period 2015-2020, more than 17\% of all insurance companies' transactions are promissory note transactions. The amount of gross contributions of such companies is over UAH 50 billion, the amount of income from the sale of securities is UAH 35 billion, and the amount of expenses for their purchase is UAH 30 billion.

Thus, based on the results of the analysis, it can be concluded that among all operations of insurance companies, more intensive control by regulatory authorities should be subject to: pseudo-insurance operations; concluding an insurance contract with subsequent receipt of compensation for the occurrence of a fictitious insured event; concluding an insurance contract with an inflated insurance value of the object.

Reinsurance operations play a key role in shadow transactions with financial intermediaries. These operations serve as an effective tool for concealing income, reducing the transparency of insurance transactions (Fig. 2).

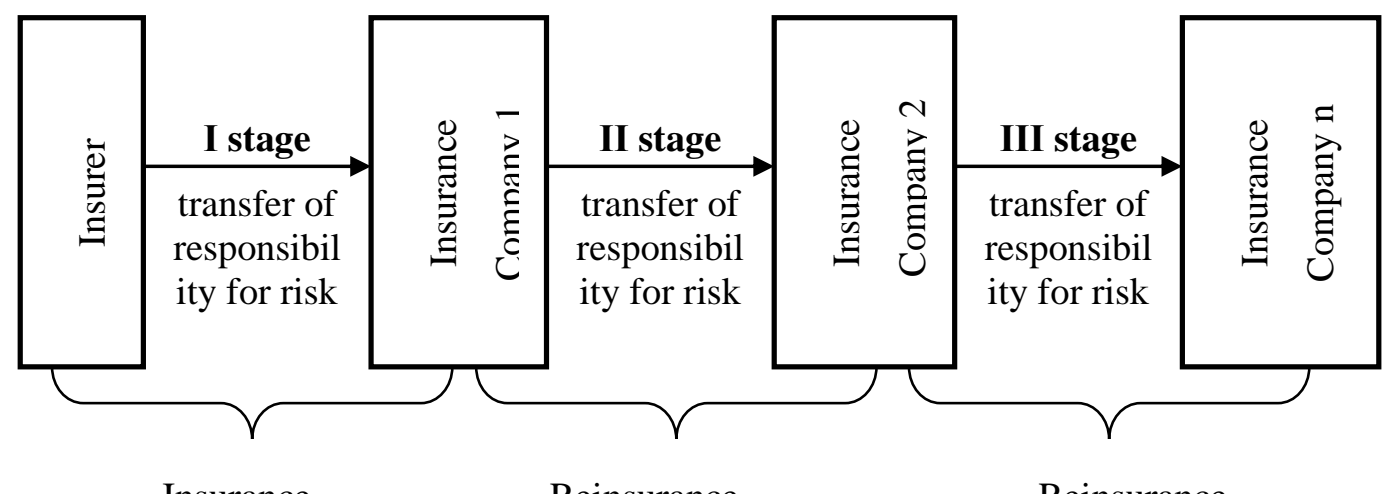
Insurance
Reinsurance
Reinsurance

Figure 2. The relationship of insurance and reinsurance operations in the shadow schemes of withdrawal

Source: Compiled by the author.

The initial stage of shadowing of income with the participation of insurance companies is the conclusion of an insurance contract, the subject of which is the transfer of responsibility for risk to the insurance company. In accordance with the terms of this agreement, the insurance company assumes all risks and in the event of an insured event undertakes to pay compensation in exchange for insurance payments received from the insured. 
Almost $70 \%$ of premiums paid under insurance contracts are transferred to non-residents for reinsurance. This is due to the implementation of insurance companies' pseudo-insurance operations. At the same time, a significant part of these transactions is implemented by companies that do not have the legal right to carry them out. These trends confirm the hypothesis of active use of pseudo-investment operations in the process of legalization of illegally obtained income.

2) the risk of shadow transactions with the participation of investment market participants. Today, economic entities use a wide range of investment instruments of shadow withdrawal, which can be divided into three groups: direct, portfolio and financial (Christensen \& Kapoor, 2004; Mara, 2021).

1. Portfolio investments include funds invested in debt or equity securities. Today, a common practice in most countries of the world is the shadowing of income and their further legalization through investment operations in derivative securities. Portfolio investment creates additional opportunities for the withdrawal of profits to the recipient's country of origin with their subsequent shadowing or tax evasion.

2. Transactions with technical securities play an important role among investment instruments of income shadowing and their further legalization. Quite often the value of such securities is not secured by real assets, and therefore is subject to manipulation by participants in the shadow sector of the economy through the implementation of the following schemes:

3. Sale of technical securities at a value several times lower than their nominal value. After that, these securities can be sold on the market at inflated prices.

4. Issuance of fictitious (non-existent) securities. Thus, according to the State Tax Service of Ukraine, in the country more than 420 economic entities carry out operations with counterfeit bills whose nominal value exceeds UAH 16.5 billion.

5. Carrying out transactions with technical securities in order to increase costs and thus minimize corporate income tax liabilities. The share of these transactions in the securities market in recent years exceeds $15 \%$.

6. Issue of technical securities in order to increase the authorized capital of such a company. These economic entities form their own authorized capital with the subsequent withdrawal of funds through the purchase of technical securities.

7. Realization by domestic economic entities of a non-resident of technical securities at a reduced value with their subsequent purchase from a non-resident at a price above the market price. The implementation of these operations allows you to withdraw funds abroad, including in offshore countries. In addition to the direct withdrawal of funds abroad, these transactions contribute to the tax evasion of economic entities.

\section{Conclusions}

The constant growth of the level of the shadow economy in Ukraine, highlights the need for a more comprehensive study of all possible tools for concealing income and identifying participants in these schemes. The results of the analysis show the active participation of financial intermediaries in shadow schemes of income concealment. These entities act as intermediaries and direct participants in these transactions. Thus, strengthening control over their activities, closer attention by regulatory authorities to operations carried out with their direct participation is a necessary prerequisite for the implementation of policies to de-shadow the economy and prevent money laundering.

\section{Author Contributions}

Conceptualization: Tiutiunyk, I., Yuliia Humenna, Yu.; methodology: Tiutiunyk, I., Yuliia Humenna, Yu.; software: Tiutiunyk, I., Yuliia Humenna, Yu.; validation: Tiutiunyk, I., Yuliia Humenna, Yu.; formal analysis: Tiutiunyk, I., Yuliia Humenna, Yu.; investigation: Tiutiunyk, I., Yuliia Humenna, Yu.; resources: Tiutiunyk, I., Yuliia Humenna, Yu.; data curation, Tiutiunyk, I., Yuliia Humenna, Yu.; writing-original draft preparation: Tiutiunyk, I., Yuliia Humenna, Yu.; writing-review and editing: Tiutiunyk, I., Yuliia Humenna, Yu.; visualization: Tiutiunyk, I., Yuliia Humenna, Yu.; supervision: Tiutiunyk, I., Yuliia Humenna, Yu.; project administration: Tiutiunyk, I., Yuliia Humenna, Yu.; funding acquisition: Tiutiunyk, I., Yuliia Humenna, Yu.

Funding. This research was funded by the grant from the Ministry of Education and Science of Ukraine "Formation of Tools for the Ukrainian Economy Unshadowing Based on Causal Modeling of Interaction Trajectories of Financial Intermediaries" (№0120U100473). 


\section{References}

1. Almenar, V., Sánchez, H. L., \& Sapena, J. (2020). Measuring the shadow economy and its drivers: the case of peripheral EMU countries. Economic Research-Ekonomska Istraživanja, 33:1, 2904-2918. [GoogleScholar].

2. Christensen, J., \& Kapoor, S. (2004). Tax Avoidance, Tax Competition and Globalization: making tax justice a focus for global activeism. Accountancy Business and the Public Interest, 3(2), 6-9. Available at: [Link].

3. Del'Anno, R. (2003). Estimating the shadow economy in Italy: A structural equation approach, Discussion Paper, Department of Economics and Statistics, University of Salerno. [Link].

4. Doyle, N., Hermans, L., Molitor, P., \& Weistroffer, C. (2016). Shadow Banking in the Euro Area: Risks and Vulnerabilities in the Investment Fund Sector. ECB Occasional Paper Series, 174. [Link].

5. F'eve, P. \& Pierrard, O. (2017). Financial Regulation and Shadow Banking: A SmallScale DSGE Perspective. TSE Working Paper, 17-829. [Link].

6. Farhi, E. \& Tirole, J. (2017). Shadow Banking and the Four Pillars of Traditional Financial Intermediation. NBER Working Paper, 23930. [Link].

7. Favarel-Garrigues, G., Godefroy, T., Lascoumes, P. (2007). Sentinels in the Banking Industry: Private Actors and the Fight against Money Laundering in France. British Journal of Criminology, 48(1), 1-19. [Link].

8. Hepfer, B., Wilde, J., \& Wilson, R. (2016). Taking Shadow Insurance Out of the Shadows: Regulatory Arbitrage, Taxes, and Capital. [Link].

9. Illicit Financial Flows Reports. Global Financial Integrity official web-site. [Link].

10. Johnson, J. (2003). How will the financial services sector respond to the Financial Action Task Force's increased customer due diligence requirements. Journal of International Banking Regulation, 5(2), 127145. [Link].

11. Koldovsky, M. V. (2008). Worldwide experience in combating money laundering in the banking sector: the current conditions of financial markets globalization. European vector of economic development, Vol. 1, No. 4, pp. 26-32. [Link].

12.Mara, E. R. (2021). Drivers of the shadow economy in European Union welfare states: A panel data analysis. Economic Analysis and Policy, 72, 309-325. [Link].

13.Melnyk, M., Zhabynets, O., Myshchyshyn, I., \& Orlov, V. (2021). Efficient use of the insurance sector potential adjusted for its shadowing: Case of Ukraine. Insurance Markets and Companies, 12(1), 16-31. [Link].

14.Mikulić, D. (2021) Volume of the unofficial economy in the Western Balkan region. Economic ResearchEkonomska Istraživanja, 34(1), 1603-1622. [Link].

15.Shumska, S., \& Nezhyvenko, O. (2013). Shadow economy in Ukraine: methodology and evaluation. Actual problems of economics, 10(148), 74-83. [Link].

16.Tiutiunyk, I., Humenna, Yu., \& Flaumer, A. (2021). Covid-19 impact on business sector activity in the EU countries: digital issues. Health Economics and Management Review, 2(1), 54-66. [CrossRef]. 